\title{
The Worst Place on Earth to be a Woman: Violence against Yemeni Women in Peace and War
}

\author{
Maria Holt \\ University of Westminster, UK
}

\section{Keywords}

Woman violence, Women in peace, War

\section{Introduction}

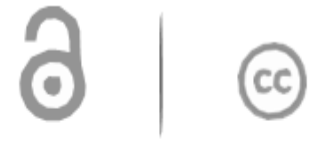

\section{G Open Access}

Citation: Holt, M. The worst place on earth to be a woman: violence against Yemeni women in peace and war. Gender and Women's Studies. 2020; 3(1):2.

Received: June 10, 2019

Accepted: March 16, 2020

Published: April 16, 2020

Copyright: () 2020 Holt, M. This is an open access article distributed under the terms of the Creative Commons Attribution License, which permits unrestricted use, distribution, and reproduction in any medium, provided the original author and source are credited.

\section{Corresponding author:}

Maria Holt, University of Westminster, UK

E-mail: M.C.Holt01@westminster.ac.uk
In April 2011, Ali Abdullah Saleh, then president of Yemen, criticized women for 'inappropriately mixing in public with men' at the massive demonstrations taking place in several cities across the country (Cole \& Cole, 2011). At the start of the revolution, mixing of the sexes was uncontroversial, as in Tunisia and Egypt. Many 'fathers, brothers, and husbands encouraged their female relatives to participate' (Alwazir, 2012). However, this inclusive approach gradually changed in Yemen as 'Islamist hardliners' started to assert their power in public spaces. Some women report being beaten; some were subjected to rumour, threat and harassment by religious and political forces 'in attempts to silence them' (Alwazir, 2012). The Islamist Islah faction ${ }^{1}$, in particular, were keen to segregate the sexes and, in Sana'a, 'women were forced to sit in a separate yard... covered by heavy curtains and locked behind a thick iron gate'; Islah members argued that 'it was haram ${ }^{2}$ for men and women to mix publicly' (Haddad, 2012). Although Yemeni women's public visibility was somewhat unexpected, the reaction to it was nothing new. Since 2006 Yemen has ranked last in the Global Gender Gap Index ${ }^{3}$ and has been described as 'the worst place on earth to be a woman'. What was noteworthy, however, was that women resisted this infringement on their rights as citizens and, in the face of female outrage, President Saleh quickly backed down, claiming instead that women should be 'full participants in the political affairs of the nation' (Cole \& Cole, 2011).

While women were very much in evidence in popular protests across the Middle East and North Africa (MENA) region in 2011, their involvement surprised many outside observers, who had tended to regard Arab women as 'passive, docile, incarcerated inside a repressive religion, denied a public presence' (Dabashi, 2012, pp. 182-183). In Yemen, a country 'where the cultural, political and economic gaps between men and women are some of the largest in the world', not only were women demonstrating, often at great personal cost, to express their discontent with the ruling regime, they were 'a leading force behind the cultural evolution that powered the revolutionary movement' (Haddad, 2012). In common with women in other Arab states, Yemeni women dared to raise their voices in the public sphere and to call for change. Evidence of women's revolutionary engagement throws into question assumptions of female powerlessness and silencing in Muslim societies, and my article will explore whether and to what extent

\footnotetext{
${ }^{1}$ The al-Islah Party is an affiliate of the Muslim Brotherhood and a legal political party, regularly winning seats in the Yemeni parliament

${ }^{2}$ Haram (Arabic): forbidden or proscribed by Islamic law

${ }^{3}$ In March 2019, Yemen was ranked $149^{\text {th }}$ out of 149 countries in terms of 'overall gender equality'
} 
Yemeni women's behaviour during the revolution and afterwards was a departure from their previous roles. It will also reflect on more far-reaching processes of change in Yemeni society by asking whether the radical upheaval of 2011 may be capable, in the longer term, of challenging entrenched patriarchal structures in order to create a more genuinely inclusive citizenship. Since the relatively optimistic days of 2011, however, Yemen has descended into a catastrophic civil war, which throws into doubt the courage and determination shown by women and raises the urgent question of whether the forces of violence and chaos, for so long hovering on the margins of Yemeni society, have finally succeeded in extinguishing the small but persistent voices of women.

In the article, I will contrast Yemeni women's activism and their presence in public spaces with the various forms of violence that limit their mobility and choices. I will argue that, although they have been able to utilize the limited tools at their disposal in order to demand their rights as citizens, these rights are by no means guaranteed; they are threatened by the violence of tradition and, more recently, the violence of conflict and emergency. Women have had to overcome not simply male prejudice, as articulated by President Saleh and the Islah Party, but also the rigid gender structure of their society. In doing so, many women have demonstrated high levels of agency but, I argue, it is not enough. To test my argument, I propose to critically analyze, first, the shape of women's oppression in Yemen and the multiple violences they suffer; second, how they challenge constraints on their behaviour, which are sometimes imposed in the name of religion and 'proper' behavior; third, some of the ways in which Yemeni women have participated in struggles against ruling regimes; and, finally, the implications their involvement in the protests might have for future democratic trends. At the same time, it is impossible to ignore the current reality; given the destructive civil war that has reduced Yemen and its people to a 'humanitarian catastrophe', in which survival inevitably has taken precedence over the niceties of rights and equality, women have seen their space for manoeuvre drastically curtailed in an extreme version of the 'retreat of women's rights' (al-Rahim, quoted in Coleman, 2012), visible in the aftermath of the 'Arab spring' uprisings across the region.

Material for this article comes from several fieldwork visits to Yemen. I conducted research in Sana'a and Aden, the two main cities of Yemen, in 1995, 1996, 2003 and 2010. ${ }^{4}$ My interviews were mainly with relatively elite women, such as lawyers, academics, civil society activists, journalists and the politically active, but I also conducted several focus groups with female students in Sana'a (in 2010) and interviewed a small number of non-elite women and several men (journalists, businessmen, lawyers, politicians, diplomats and community leaders). ${ }^{5}$ My own position as a western researcher and activist is relevant for two reasons: on the one hand, as an advocate for a deeper understanding of the Arab world in the west, I was keen to improve relations between Yemen and the UK; on the other hand, as a feminist and gender specialist, I was interested in contributing to knowledge about Yemeni women. During visits to Yemen, I had the opportunity to develop contacts with a wide range of Yemenis and a deep appreciation of the complexities of the country and its politics. I discovered that, although they face significant oppression,

\footnotetext{
${ }^{4}$ Between 1999-2004, I undertook an oral history project of the final years of British colonial rule in southern Yemen; this included interviews with British and Yemeni individuals who experienced this period. In 2003, I visited Sana'a and Aden as part of this project. In 2010, I spent some time in Sana'a, interviewing women as part of a research project on 'women and Islamic resistance in the Arab world'

${ }^{5}$ In total, over four visits, I interviewed approximately 50 individuals, either on a one-to-one basis or in groups. Interviews took place in people's homes and places of work or in community centres, universities and NGOs.
} 
many Yemeni women are aware, articulate and engaged in their society; they understand well the limitations of their position and have been working hard to reform it. One of the tragedies of the conflict is the brutal halting of progress as Yemeni civilians struggle simply to keep themselves and their children alive.

\section{Background: a fragmented nation}

Yemen has been described as 'an oddity' (Dresch, 2000, pp. 1), and to do it justice "would require extensive cross-referencing to imitate at least the "feel" of Yemen, that endless overlapping of local knowledge which makes life there, and not least political life, richly textured' (Dresch, 2000, pp.1). For centuries, Yemen, called 'Arabia Felix' (happy or flourishing Arabia) by the Romans and home to the legendary Queen of Sheba, was the primary producer of coffee, exported through the port of Mocha. In 1839, Captain Haines took the southern city of Aden for the East India Company's Bombay Presidency (Dresch,2000, pp. 3) and a protectorate was set up by the British Empire in the southeastern part of the country. Shi'a religious leaders declared a kingdom in North Yemen in 1918 and gained independence from the Ottoman Empire. A six-year civil war in the 1960s, in which Egypt and Saudi Arabia backed opposite sides, saw the overthrow of the kingdom and the establishment of the Yemen Arab Republic (UN Foundation 2017). Following a fierce independence struggle in the south, the British were forced to withdraw from Aden and the surrounding areas in November 1967.

Until 1990, Yemen comprised two independent states: the Yemen Arab Republic (YAR) in the north, characterized by tribal values, religious conservatism and a deep-rooted patriarchal culture; and the People's Democratic Republic of Yemen (PDRY) in the south, described as a 'unique socialist experiment in the Arab world' (Lackner, 2017, pp. 677). In May 1990, these two very disparate states unified to become the Republic of Yemen, at which time the north had a population of around 11 million while the south's numbered approximately 2.5 million. The former governments remained in place as parties: the General Popular Congress (GPC) which had ruled the north and the Yemeni Socialist Party (YSP) that had ruled the south. Ali Abdullah Salih, general secretary of the GPC, became the president of the new republic (Dresch, 2000, pp.186), a position he retained until his overthrow in 2011.

Today, the Republic of Yemen 'ranks as a lower-middle-income, least developed nation' (Carapico, 1998, pp.14). It is the poorest country in the Arab world, and has very high birth rates and low literacy, especially among women (Carapico, 1998, pp.14); almost 60 per cent of Yemeni women are illiterate (UNICEF 2012). Despite the relatively progressive policies of the south prior to 1990, the new republic, heavily dominated by the north, developed along conservative lines. According to its constitution, Yemen is governed by a democratic, parliamentary system; however, in reality governance is corrupt, inefficient, deeply influenced by tribal allegiances and reliant on Islamic law in matters of personal status. It is a traditional society, and also a very pious one, with clearly defined spatial arrangements and notions about appropriate behavior for both sexes. A combination of poverty, a lack of education, a stagnant political situation and an entrenched patriarchal gender structure has ensured that Yemen's women are constrained in terms of choices and opportunities. They also endure high levels of violence.

\section{Violence against women in Yemen}

The sheikh tied her up against a pole in the middle of the street and 
asked the locals to spit on her. He said she was the devil's child. ${ }^{6}$

The 'devil's child', in this case, was a 15-year old girl in Hodeida; accused by her father of 'being immoral' for playing outside with her friends and handed over to a local sheikh; the girl was married off to an older man, who also abused her. Believing she was worthless, the girl fled to Sana'a and was eventually taken in by the Yemeni Women's Centre for Empowering Women (Al-Sakkaf 2010). Her story encapsulates the second-class status afforded to women and girls in Yemen and the routine violence practiced against them. But it also shows that avenues are being created, in the shape of organizations to help and support women, to challenge some of the more iniquitous abuses of women's rights.

Throughout the narrative of Yemeni women's activism, we find a persistent thread of violence, especially domestic violence. Intimate partner abuse has been identified as 'one of the most widespread human rights abuses and public health problems in the world today' (Crawford, Liebling-Kalifani \& Hill, 2009, pp. 63, Velzeboer \& Novick, 2000). Such violence, whether in the west or less developed countries such as Yemen, takes place within a patriarchal environment in which men's needs and entitlements are placed above women's. It 'forms an integral aspect of male dominance because the systems of power and authority are ultimately based on the threat or use of force' (Wagers, 2015, pp. 232; Dobash \& Dobash, 1988). The patriarchal gender order relies on violence and coercion in order to ensure that women remain 'in their place' (Erturk, 2016, pp. 31). Yemeni women are subjected to violence both in the private spaces of their homes. through discriminatory laws and public policies that discriminate against them and even in public at the hands of strangers.

This situation is further exacerbated by the involvement of religion. Religious laws, which 'encompass ideals of male dominance over subordinate women and children' (Maktabi, 2010, pp. 557), can often be seen as coming into conflict with the state's body of public laws and, 'because family law has judicial primacy in defining women's personal status, the constitutional rights of female citizens are rendered invalid' (Maktabi, 2010, pp. 558). This places women at a clear disadvantage and limits their ability to participate in the political community; it also means they are at a greater risk of violence within the household. In patriarchal societies such as Yemen, power tends to be associated 'with masculinity and violence against women is a means by which men express their power and masculinity' (Baobaid, 2006, pp. 161); the patriarchal power structure of Arab societies in general 'justifies inequality between men and women' (HajYahia, 2000, pp. 240-241) and this is reinforced through religious belief. In addition, although violence against women is a global problem, attitudes towards it and ways of dealing with it differ widely between states and cultures. In Arab and Islamic societies, according to Douki et al, 'domestic violence is not yet considered a major concern' (2003, pp.165) although, in some Arab states, perceptions of women's rights and entitlements are now beginning to shift although, in this respect, Yemen still has some way to go.

The use of particular tools, including violence, to control women's behavior is linked to the construction of gender regimes. Terry, Hogg and White argue that 'people are influenced by norms not for social approval, nor because others have told them to, nor because others are watching but because norms prescribe the context-specific attitudes and behaviours appropriate for group members' (2000,7 pp. 2; Almosaed, 2004, pp. 71). This is very apparent in

\footnotetext{
${ }^{6} \mathrm{Al}$-Sakkaf 2010.
}

${ }^{7}$ Religious leader. 
Yemen and can be explained by several factors. First, as Terry, Hogg and White point out, it is associated with 'context-specific attitudes and behaviours appropriate for group members' (2000:72). Their argument builds on what Suad Joseph calls the 'persistence of patriarchy' in the Arab world. She argues that patriarchy works because it becomes part of 'one's sense of oneself as a person' (1996:18); it creates 'a hierarchy of authority that is controlled and dominated by men' (Krauss, 1987, pp. xii) and internalized by all members of society. This situation is particularly pronounced in Yemen, a context in which appropriate forms of behaviour for males and females have been idealized and where men exercise absolute control and women possess few freedoms. Second, intimate partner violence is widely justified in some Arab states. The National Union of Tunisian Women suggests three reasons for this: it is seen as a 'religious practice' that considers wife-beating a duty for the husband; there is a close linkage between wife-abuse and the economic dependence of women; and, in traditional marriages, men tend to tolerate and justify marital violence (UNFT, 2002). Again, the Yemeni example provides ample evidence for such claims. Third, although there 'is a wealth of evidence that indicates that the consequences of domestic violence are often devastating and long-term' (Crawford, Liebling-Kalifani \& Hill, 2009, pp. 63-64), Yemen lacks appropriate infrastructure or resources, or even commitment, to address either the results or the underlying causes.

This implies that Yemeni women have no choice but to accept the 'specific context' of their lives and have somehow normalized the violence they suffer, as we see in the case of the young woman from Hodeida. However, reality is more complex in the sense that women have positive feelings towards Islam but harbor increasing doubts about the restrictive and arguably non-Islamic gender regime that men have constructed, a regime in which violence is an unchallenged factor. To explore the culture of violence further: a survey on violence against women in Yemen revealed that 55 per cent have been abused physically, 34 per cent have been victimized financially, and 17 per cent have been victims of sexual violence. Most women 'report psychological damage as a consequence of the abuse and hardly ever seek help from the police'. Worse, it was revealed that 'many women regard the violence they have suffered as ordinary and many regard society as being in principle against them and favouring men' (Ba-Obaid \& Bijleveld, 2002). While acknowledging that relatively little is known about the causes of violence against women in Yemeni society, the survey's authors identify four possible factors: first, economic inequality; second, the normalized use of violence to resolve conflict; third, male dominance; and fourth, divorce restrictions for women (Ba-Obaid \& Bijleveld, 2002, pp. 333; Levinson, 1989). The testimony of one woman confirms the 'absolute dominance of men over women'; according to her, 'women have no rights. They have to suffer; society does with us as they please. We are second class citizens. Nobody listens, nobody cares, people think this is normal but it is not normal'. Another woman agreed that 'our society is men's society. Men decide what is right and what is wrong, not only in the family but in the whole society' (quoted in Ba-Obaid \& Bijleveld, 2002, pp. 343). In 2010, I met a woman who had fled conflict in the north of the country for the relative safety of Sana'a; uneducated and unaware of her rights, this woman spoke of her fear that her husband would take another wife and, although she did not question his right to do so, she clearly felt it would be unjust. ${ }^{8}$ The words of these women confirm that gender-based violence is a fact of life but, while they have little power to stop it, many do not accept it.

${ }^{8}$ Interview, Sana'a, February 2010. 
Women also face the violence of traditional practices. According to Human Rights Watch, 14 per cent of Yemeni girls are married before the age of 15 and 52 per cent before 18 . This makes it 'difficult for them to gain access to education, is bad for their health as they have a larger number of pregnancies with no possibility of controlling them, and thus keeps them in the category of second-class citizens' (2019). The lack of basic rights for women and girls can be attributed to the patriarchal framework of Yemeni society. A 'deeply ingrained patriarchy means many women and girls cannot access their family's finances, make decisions for the household, or even move about freely. They have limited access to education, livelihoods and women's health services' (International Rescue Committee, 2019). Any deviations from the patriarchal norms of society are likely to be met with various forms of violence. This is a pattern that is not at all unique to Yemen; male control over the state, its laws and its social norms is virtually unchallenged across the globe.

Moreover, the rigid patriarchal framework of society has implications for notions of citizenship and national belonging. While former president Saleh claimed Yemeni women should be 'full participants in the political affairs of the nation' (Cole \& Cole, 2011), it is also the case that 'the nation' is a gendered category. Nations, as Yuval-Davis argues, 'are constructed by shifting nationalist discourses promoted by different groupings competing for hegemony. Their gendered character should be understood only within such a contextualization' (1997, pp. 4). Nationalism is linked to identity and, as such, it encourages individuals and states to assert what they believe to be a unique and shared identity. Yet as Steans suggests, what is also necessary in 'the process of establishing a sense of identification with the nation' is 'the telling of a particular story about the nation and its history' (1998, pp. 65). Nationalist discourses - or stories - seek to reinforce 'the idea of the nation as a continuous narrative of national progress' (Bhabha, 1990, pp. 1) but, one has to ask, whose story, whose progress? National stories have traditionally been told by men, the instigators and controllers of the narrative, with women reduced to symbol to attest to the nation's modernity or modesty.

Thus, feminist interpretations of the nation and nationalism have critiqued the classic formulation which saw 'female emancipation' as 'a powerful political symbol' encompassing at the same time, 'a separation from the past, the aspirations of an active present, and the utopia of an imagined national future' (Heng, 1997, pp. 31). By so doing, they have exposed 'blind spots' in theories of the nation that 'legitimized the exclusion of women from the public sphere' (Guibernau \& Hutchinson, 2001, pp. 4). In Yemen, the reliance on Islamic cultural norms and modes of behavior further reaffirms the exclusion of women from public space. While 'female emancipation' may have been a goal of the socialist pre-1990 south, it was never articulated as an aspiration for the newly unified state.

The more recent assessment of Yemen as 'the worst place on earth to be a woman' is based, according to western journalist Rachel Cooke, on a number of factors: the country is deeply conservative, many girls are married before they even reach puberty, and many die in childbirth (2008). In 2010, the Englishlanguage Yemen Times reported the story of 10-year old Aisha, forced to marry an older man and to have sex with him. In Aisha's words: 'He took out a special sheet and laid me down on it. After it, I started bleeding. It was so painful that I was crying and shouting, and since then I have seen him as death'. As there is no law to protect children against early marriage, there is little anyone can do but, as a lawyer at the High Court in Sana'a remarked, 'I don't call it marriage, but rape' 
(Yemen Times 2010). In response to widespread protests, Yemen has committed itself to eliminating child, early and forced marriage by 2030, in line with target 5.3 of the Sustainable Development Goals and, at the Girl Summit in July 2014, the government signed a charter to end child marriage by 2020 (Girls not Brides, 2014).

'Male power, suggests Cooke, 'is total' (2008). While there is some truth is her observation, I would argue that the reality is more nuanced. To begin with, the role of religion is somewhat contentious; it is both a tool of empowerment but also, some have suggested, of the oppressive treatment of women. In Yemen, Islam is deeply embedded in the tribal structures that dictate how people should behave and what they may do. But it is also misused. Some Yemeni women argue that Islam has been wrongly interpreted as a means of controlling their behaviour. In the words of one:

Women are made to understand that they are not welcome in the public space. Islamic movements use religion to mislead people; they use it to brainwash simple women. Many people are dissatisfied with the government so they look with hope to Islamic parties; but they will never allow women to play a role in public life. ${ }^{9}$

Her observation encapsulates the tension between Islamic politics as an emancipatory project and, at the same time, a supporter of the status quo.

\section{A tradition of Yemeni women's activism}

Despite the restrictions of their conservative of society, women in Yemen have a history of activism. As elsewhere in the MENA region, they have played a part in national liberation struggles and in protest movements for social and political change. In the 1960s, women in southern Yemen played an important role in their country's fight for liberation from British colonial rule. A woman who was active with the Front for the Liberation of Occupied South Yemen (FLOSY) recalled that, in 1963, when the revolution started, 'there were girls, women, men of Aden, all of us. ${ }^{10}$ Inspired by the efforts of women elsewhere, for example in the anti-colonial struggle of Algerians against the French, the women and girls of Aden took to the streets to demand an end to British rule, much as women across the Arab world raised their voices in protest in 2011.

Before unification in 1990, the former PDRY was regarded as being unusually progressive in terms of women's rights in the Arab region. Women participated at all levels of society; they were even permitted to serve as judges. However, once the north and south united, the conservative values of the more powerful north took precedence, much to the detriment of women. In the words of one:

After unification, they picked only the negative aspects of the north and south. Before, in the south, there was a minimum age of marriage; a man was not allowed to take a second wife, but after it became permissible. Before, girls and boys studied together, now they are separated in school. ${ }^{11}$

Women's mobility and choices were also reduced, and even their freedom of dress was limited; the all-encompassing 'Islamic dress', including full face veil, became the norm. When I visited the south in 2003, it was almost impossible to find a woman who was not fully covered although, as several

\footnotetext{
${ }^{9}$ Interview, Sana'a, February 2010

${ }^{10}$ Interview, Aden, October 2003.

${ }^{11}$ interview, Sana'a, February 2010
} 
remarked to me, this was not always by choice but because it would be too risky to go outside without a full veil. In late 2012, a 20-year old woman posted the following comment on her Facebook page: 'My face is not shameful. I have every right to walk in the street without covering my face and not be cursed or harassed by people'. While her comment attracted some support, others were more critical; said one man: 'You can't under any circumstances call into question our Islamic teachings, and you just have to take them as they are' (Shamlan, 2012). This highlights the tension between modernizing trends in Yemen before 2011 and the limitations of a highly conservative society, but it also illustrates a willful ignorance; did the male critic genuinely believe that 'our Islamic teachings' mean a woman must be fully covered or was his comment a reiteration of the status quo?

On the other hand, as I argue in this article, women in Yemen, as elsewhere, have a tradition of activism in or through Islamist politics. Their relationship with Islam is complex. While most insist they are strongly attached to their religion, they are troubled by some of the constraints placed on their lives by what they refer to as 'extremists' and 'wrongful' interpretations. A woman in Sana'a complained that men 'interpret the holy Qur'an in harmony with their interest. We know that our religion guarantees many rights for women, but men accept only what is good for them, and don't accept what is not good for them' (quoted by Ba-Obaid \& Bijleveld, 2002, pp. 343). According to another woman in Sana'a, 'the Islah Party is very extreme; they oppose women's political participation and their presence in the public domain; they believe that women should stay at home and leave employment opportunities for the men; women should not mix with men in the workplace'. ${ }^{12}$ Their comments highlight the evident frustration felt by women; they recognize that some men are willing to manipulate religion for their own ends.

Although the Islah Party exhibits conservative attitudes towards women, and these were revealed in the 2011 revolution, they have also facilitated the involvement of women, and have created 'spaces for women to organize and mobilize' (Clark \& Schwedler, 2003:308). In the words of a university lecturer in Sana'a,

women who belong to the Islah Party have more opportunities for empowerment; they hold training courses, more than women in other parties. Those women could provoke dramatic change for Yemeni women; they speak from a religious perspective and they are well organized; when they speak, they speak with confidence. Islamist women sometimes have only religious education, they feel their rights are being violated by men so they are standing up for their rights... In the struggle for women's rights, these women must be engaged. ${ }^{13}$

Joseph refers to 'religious patriarchy' by which she means 'the privileging of males...in religious institutions and practices' (1996, pp.17), and this is very apparent in the Yemeni case where religion, bolstered by traditional practices, has structured a rigid gender hierarchy. But there is a paradox here. On the one hand, Islamist parties are frequently accused of constraining women and excluding them from the public world of politics and yet, on the other, as the university professor remarked, they have also offered some women a method of empowerment. A young activist agreed; 'Islamic groups realize that women play an important role', she said, 'so they try to use women'. In her view, women in Islamist organizations are in a unique position because they can work within the system; this is a 'pro-

\footnotetext{
${ }^{12}$ Interview, Sana'a, February 2010

${ }^{13}$ Interview, Sana'a, February 2010.
} 
women discourse that does not conflict with the ideology of the group'. ${ }^{14}$ Her argument highlights an important nuance in Yemeni life; it would be difficult and undesirable to shape one's life outside the framework of Islamic practices; beyond its apparent restrictions on women's lives, this framework offers a rich arena for social interaction and personal development. Women wishing to challenge the system are therefore compelled to operate within the constraints and opportunities offered by religion.

Like Islamist parties elsewhere, Islah has worked hard with women at the grassroots level; according to a woman in Sana'a, 'in the political field, women Islah members play a vital role; they go from house to house to convince other women - they are very active'. ${ }^{15}$ Another woman explained that there are different wings in the Islah Party, some are moderate and others extremist. The majority of Yemeni women, she added,

are indirectly engaged with the concepts of these Islamist movements. The structure is very conservative and male-dominated. This pushes women to accept such ideologies; religion plays a crucial role in forming the ideas of ordinary people. It is easy to relate everything to the Prophet and then people will accept it. ${ }^{16}$

One gains a sense of the contradictory arguments being articulated by the various women quoted in this article. On the one hand, there is a sense that Islam can be genuinely empowering and liberating for women and is capable of providing them with space for development and public engagement. Others, however, take a more pessimistic view, observing that women are 'forced' into accepting what men tell them because it comes from the Prophet. The pragmatic approach adopted by younger, educated women, is that women, like men, should use Islam, distinguishing between the 'real' and 'false' meanings being propagated.

\section{Yemeni women and revolution}

In popular demonstrations in Tunisia and Egypt, in early 2011, women were 'visible and effective' (Kandiyoti, 2011), and this pattern was repeated in other countries that joined the revolution. It is important, however, to distinguish between the status of women in individual states. While Tunisian women have 'been in the vanguard of protest movements and social change since the drive to gain independence from France in the late 1940s' (Cole \& Cole, 2011), Yemeni women have faced a more uphill struggle for visibility. Nonetheless, despite the rigid gender system which structures their lives, they too found the courage to go out on to the streets. The events in 2011 in Yemen, in the view of Helen Lackner, 'amounted to a revolution - of a unique kind'. The label 'revolution', she believes, is justified, first, because 'the movement reflected a fundamental change in the country's political discourse'; second, the uprising 'was a mass movement, involving a substantial proportion of the country's population'; third, it involved broad sections of society, 'overcoming traditional regional and social divisions'; and, fourth, the movement had political objectives that 'called for a fundamental transformation of the country's political system' (2016:142). It was certainly a revolutionary moment for women. During the revolution in Yemen, the presence of women in the public sphere became 'an iconic symbol of women's empowerment'. They came from various backgrounds and locations and

\footnotetext{
${ }^{14}$ Interview, Sana's, February 2010.

${ }^{15}$ Interview, Sana'a, February 2010.

${ }^{16}$ Interview, Sana'a, February 2010.
} 
participated at all levels. They were present on the front line, and also volunteered for various committees in the public squares; they nursed the wounded, prepared food for the revolutionaries, documented the uprising, and encouraged family members to be steadfast (Alwazir, 2012). In the words of a journalist: 'Thanks to the uprising of 2011, the visibility of women in Yemen has skyrocketed...the cultural stigma against Yemeni women's participation in the public sphere has suddenly disappeared' (Al-Sakkaf, 2012). Given the tension I have identified between various forms of violence against women, on the one hand, and the need to include them in the nation-building project, on the other, their presence in the public square should be regarded as highly significant.

One of the most prominent faces of the Yemeni revolution was that of woman: Tawakkul Karman, Nobel Peace Prize winner in 2011 and social activist. She was at the forefront of popular protest and camped out in the centre of Sana'a for several months. According to her, the problem lay with the ruling party, not with the Islamist groups. Despite the presence of conservative people in the Islah party, there are many open-minded people, she said, 'who are now fighting for the freedom of women'. ${ }^{17}$ Her analysis is interesting and suggests a more nuanced approach to Islamist politics and how they include or exclude women, as suggested by some of my interviewees. At the same time, the strategy of some of the more ideologically extreme sections of the movement raises questions about what the future might hold for women should such groups become more powerful in the future. Some of the women I spoke to before the 2011 uprising expressed concern about the rising power being claimed by conservative elements of the party, which was spreading through the society and restricting women's already limited freedoms in areas such as access to education, minimum age of marriage and exclusion from the public space.

Following the handover of power by former president Saleh to his deputy Abd Rabu Mansour al-Hadi, at the end of 2011, a national unity government was formed. between the former ruling General People's Congress (GPC) and the opposition Joint Meeting Party (JMP). Although women's political participation was seen as a priority, many women started to feel 'that the disputing political parties will unite around only one issue: excluding women' (Alwazir 2012). As has happened in so many other revolutionary struggles, once the battle has been won, women are compelled to resume their former roles, which tend to be domestic and circumscribed. Their participation, in other words, is symbolic rather than substantive. In a report based on a series of focus group discussions following the uprising, Oxfam revealed that, even though 'a transition toward democracy is under way, women's hopes for a better life are wearing thin'. The report added that continued conflict and insecurity throughout much of Yemen is 'exposing women to violence and risking their safety' (2012). This apparent 'retreat in women's rights', according to al-Rahim, 'has more to do with the resurgence of patriarchal, narrowly conservative social mores embedded in ancient tribal customs than with religion' (quoted in Coleman, 2012).

But there were more positive signs. A National Dialogue Conference (NDC) was established as a requirement of the Gulf initiative in 2011, in order to tackle Yemen's political tribulations and increasing instability, and this was regarded as a positive development by women participants who identified significant problems in the area of women's rights. Yemen is one of only two countries in the world with no legislation regarding the minimum age of marriage. Yemeni doctor Nawal Ba Abbad argued at the time that, with a 'national dialogue

${ }^{17}$ Interview, Sana'a, February 2010. 
underway to establish a new constitution, there is now a chance to establish a safe age of marriage, protecting young girls who are currently married off as young as nine years old'. Dr Ba Abbad relates the story of her childhood friend, who was 'the smartest girl in our class'. When she was 13, the girl was told 'to leave school to prepare for her wedding. Her dreams ended' (2014).

Nonetheless, according to the country's transitional Prime Minister, Muhammad Salim Basindwa (2011-2014): 'Yemeni women are important factors in our development, and Yemen will prosper only if women are fully involved' (Parker, 2012). He pledged his support for the demand by women's organizations that an electoral quota be introduced (Al-Sakkaf, 2012). Tawakkol Karman commented that 'the civic vibrancy of Yemeni society', following the uprising, proved 'particularly beneficial for women, who increased their participation in the public sphere' (2018, pp. 217). According to her, women's involvement in the National Dialogue Conference, 'remains a prominent landmark' (2018, pp. 217). The conference set a quota whereby women had to make up at least 30 per cent of all elected and non-elected decision-making positions. In Karman's view, women's efforts and 'constructive proposals' helped to make 'the conference's final document among the best political documents Yemen has ever known' (2018, pp. 217). However, despite good intentions, there is a gulf between political documents and reality on the ground; for many Yemenis, early marriage for girls is regarded as a social norm and religiously sanctioned.

\section{Women and war in Yemen}

Life for Yemenis has significantly declined since the hopeful period following the revolution, as civil war and external attack take their toll on a population already afflicted by instability and an inability to meet basic needs. Yemen has long been an arena of violent contestation. In 2000, 17 US personnel were killed when an offshoot of al-Qa'ida, known as al-Qa'ida in the Arabian Peninsula (AQAP), bombed the USS Cole in the port of Aden, focusing attention on 'a rapidly expanding terrorist threat inside ungoverned areas in Yemen' (UN Foundation, 2017). President Saleh, backed by Saudi Arabia, launched a series of attacks in 2004 against a group of Zayidi (Shi'a) fighters in northern Yemen, the Houthis. ${ }^{18}$ In the wake of the 2011 revolution and the overthrow of President Saleh, the Houthis, who are bitterly opposed by Saudi Arabia and have cultivated a relationship with Shi'a Iran, took the opportunity to advance militarily; in alliance with the former president, they took control of parts of the country, forcing the newly installed government of Abd Rabu Mansour al-Hadi to flee to Saudi Arabia, 'leaving the Houthis in practical, if not legal, control of the institutions of the state' (UN Foundation, 2017).

In 2015, a coalition of nine countries, led by Saudi Arabia, began a bombing campaign against the Houthi. The civil war, described as 'one of the gravest humanitarian crises of the modern era', has led to the deaths of over 80,000 people and placed 11 million at risk of famine (Amnesty International 2019). The Saudi-led coalition 'has conducted scores of indiscriminate and disproportionate airstrikes killing thousands of civilians and hitting civilian objects in violation of the laws of war, using munitions sold by the United States, United Kingdom, and others, including widely banned cluster munitions' (Human Rights Watch, 2018). On the whole, this carnage is taking place in an international community that appears indifferent to Yemeni suffering.

\footnotetext{
${ }^{18}$ Zayidi Shi'is comprise $40-45 \%$ of the Yemeni population, with Sunni Muslims making up most of the remainder. However, Zayidi Shi'ism is distinct from Shi'ism in Iran.
} 
During periods of violent conflict, the everyday violence suffered by women is likely to intensify and this will inevitably have an impact on an already precarious gender regime. At such times, as McWilliams argues, 'the categorization of violent acts in the context of the family, the community and the state may be even less appropriate, because the locus for the abuse is not tied to any single category but instead becomes a pervasive and interactive system' (1998,1pp.13). In 2018, Yemen 'ranked poorly on access to healthcare, economic resources, the risk of cultural and traditional practices and non-sexual violence', including conflict-related violence and forms of domestic physical and mental abuse (Thomson Reuters Foundation, 2019). Under such conditions, women tend to be more vulnerable to violence and exploitation. According to a survey, even before the conflict began 'gender-based violence was widespread. Some 92 per cent of women said that violence against women was common in the home' (UNFPA, 2016). The war has impacted on all levels, including women's personal lives and relations, said the director of a women's shelter. 'We have noticed that domestic violence has increased and the divorce rate is on the rise' (UNFPA, 2016).

The International Rescue Committee (IRC) also confirms that war 'has a unique impact on women and girls, exacerbating preexisting vulnerabilities and inequalities rooted in patriarchal structures and norms' (2019). In their view, women and girls are paying the price for the war in Yemen. They recommend that humanitarian actors should increase the priority given to the needs of females, with a specific focus on the prevention of gender-based violence (2019). These accounts charting the impact of war on women suggests that the gender hierarchy in Yemeni society has become unbalanced as men reinforce their patriarchal dominance by assuming roles as warriors or, in extreme cases, unbounded predators. It appears, too, that Islam as a moderating influence has been muted.

At the same time, according to Human Rights Watch, women activists have managed to play a prominent role during the conflict, 'advocating for better rights protection and protesting mistreatment'. However, some of the women 'have been threatened, subjected to smear campaigns, beaten and detained in retaliation' (2018), which is pattern repeated across conflict zones. Women in Yemen, they add, 'face severe discrimination in law and practice' (2018). There is a consensus that violence against women has increased; an estimated three million women and girls were at risk of violence by 2018, according to the UN. For example, forced marriage rates, including child marriage, have increased. As discussed, Yemen has no minimum age of marriage. Women and girls 'cannot marry without the permission of their male guardian and do not have equal rights to divorce, inheritance, or child custody. Lack of legal protection leaves them exposed to domestic and sexual violence' (Human Rights Watch, 2018).

Even before the war, as I have noted, Yemen was one of the most difficult places to be a women and violence against women was widespread. But the conflict has worsened the situation, with abuse and assaults against women increasing by 63 per cent (UN). In a patriarchal society such as Yemen, in the words of the IRC, 'men are viewed as providing a "protective layer" for families. Without such protection, women are exposed to physical attacks and sexual harassment' (March, 2019). The Washington Post describes the conflict as 'a man-made war paid for by women and children...they are the ones most likely to be displaced and abused'. They report that

more women are being widowed by the war each day, left without the education or skills to support their families. Rape and domestic violence are increasing. Girls are being pulled out of school to be married off for dowry 
money. Children are falling sick from diseases that were long-ago eradicated elsewhere in the world, and pregnant women and new-born babies are succumbing to starvation (Wadekar 2018).

These grim statistics highlight the victimized status of Yemeni women and reinforce the image from outside of Arab women in general as 'incarcerated within a repressive religion'. However, this simplistic reaction hardly does justice to the complex reality of Yemeni women's lives; while lack of education certainly plays a role, Islam is regarded positively by most women and many are robustly challenging the 'victimized' characterization of their lives.

\section{The future for women in Yemen}

There are also glimmers of hope. According to gender activist Suha Basharen, despite the conflict, the situation could 'open windows of opportunity' for women. Many women have unexpectedly found themselves responsible for their families, a responsibility for which they were not prepared. In large parts of Yemen, observed Basharen, 'the social norm is women belong to the house, men go out and provide for the family'. However, with the fighting, these norms have been disrupted and, 'thanks to promoting women's economic empowerment and helping female entrepreneurs access training, we're already seeing how some women are turning their traditional skills, whether cooking or sewing, into a business' (Brady 2019). While acknowledging that there are obstacles in the way of women's progress and greater equality in Arab societies, there are also a number of more positive developments. The recent focus on women's agency has played a critical role in expanding debates about gender in non-western societies 'beyond the simplistic registers of submission and patriarchy'. In particular, it has provided 'a crucial corrective to scholarship on the Middle East that for decades had portrayed Arab and Muslim women as passive and submissive beings, shackled by structures of male authority' (Mahmood, 2005, pp.115). However, 'gender roles and relations, and women's rights, are not fixed, not given, not absolute. They are negotiated and changing cultural constructs, produced in response to lived realities' (Mir-Hosseini, 2000, pp. 6). This can be seen clearly in the case of Yemen where women's rights have become increasingly contentious, especially since 1990 and even more so since the civil war began.

Women's participation in the Yemeni revolution of 2011 raises pertinent questions within the debate on nation making in the Arab world. Although most of the female revolutionaries did not articulate gender-specific demands, they began to be aware of their own lack of inclusion during the transitional period (Alwazir 2012). To support the role of women in the post-revolutionary landscape, as Haddad (2012) argues, 'one must not shy away from addressing the wider structures of economic and political oppression'. It is clear that, in many of the 'Arab spring' states, women are concerned about the future. They 'worry that on the road to new democratic parliamentary regimes, their rights will be discarded in favour of male constituencies, whether patriarchal liberal or Muslim fundamentalists' (Cole \& Cole, 2011). In other words, they fear that, fundamentally, nothing will have changed, and their concerns, in some cases, are being realized.

\section{Conclusion}

I have argued in this article that, despite excessively high levels of violence and male control, Yemeni women have displayed remarkable resilience and a determination to challenge some of the unjust laws and norms that shape 
their society. They do this on the basis that such conventions do not derive from Islam but, rather, from imperfect interpretations, whether deliberate or not, by men. I believe that the role of women in the Arab revolutions was an important indicator of change and, in this article, by examining the particular experiences of Yemeni women, I have sought to show that women have not been afraid of appearing in the public space, alongside men, to demand the overthrow of oppressive regimes However, their public visibility is always conditional and has not translated into more equal citizenship, partly as a result of existing inflexible gender hierarchies and partly because of civil war which has killed thousands of civilians, including women and children.

Yemeni women's confidence comes both from outrage and humiliation and also a history of activism. In order to encourage political empowerment for women in Yemen, there need to be cultural changes and institutional changes. However, the deterioration in their status since the start of the war in 2014 and the escalating levels of violence against them illustrates in bleak terms how quickly progress can be reversed. The rise in male violence against women raises troubling questions about unbalanced gender relations and the propensity, during periods of instability, to punish women and exclude them from the national narrative.

\section{References}

Almosaed, N. (2004). 'Violence Against Women: A Cross-cultural Perspective', Journal of Muslim Affairs, 24(1); pp. 67-88.

Al-Sakkaf, N. (2012). 'Yemen's Women and the Quest for Change: Political Participation after the Arab Revolution', Perspective, Friedrich Ebert Stiftung, October.

Al-Sakkaf, N. (2010). "initiatives to alleviate Yemeni women's suffering', Yemen Times, 25 February.

Alwazir, AZ. (2012), 'A long road ahead for Yemeni women', Open Democracy, 3 December. Rederived from: http://www.opendemocracy.net.

Amnesty International. (2019). 'Statement for the Record on March $6^{\text {th }}$ Hearing "The Humanitarian Crisis in Yemen"'. Rederived from: https://www.amnestyusa.org/ourwork/government-relations/advocacy/statement-for-the-record-on-march-6th-hearingthe-humanitarian-crisis-in-yemen/

Ba Abbad, N. (2014). 'Time to stop child marriage in Yemen and give girls back their childhood', Girls Not Brides, 3 April. Retrieved from: https://www.girlsnotbrides.org/time-stop-child-marriage-yemen-give-girls-backchildhood/

Baobaid, M. (2006). 'Masculinity and gender violence in Yemen', in Lahoucine Ouzgane, editor, Islamic masculinities, London: Zed Books, pp.161-183.

Ba-Obaid, M., \& Bijleveld CCHJ. (2002). 'Violence against women in Yemen: official statistics and an exploratory survey', International Review of Victimology, 9, pp.331347.

Bhabha, H.K (1990). 'Introduction: narrating the nation', in Homi K Bhabha, editor, Nation and Narration, London and New York: Routledge, 1-7.

Brady, K. (2019). 'Empowering women in Yemen's civil war', DW, 25 October. Rederived from: https://www.dw.com/en/empowering-women-in-yemens-civil-war/a$\underline{50586064}$

Buck-Morss, S. (2003). Thinking Past Terror: Islamism and Critical Theory on the Left, London: Verso. 
Carapico, S. (1998). Civil society in Yemen: The political economy of activism in modern Arabia, Cambridge: Cambridge University Press.

Clark, J.A., \& Schwedler, J. (2003). 'Who Opened the Window? Women's Activism in Islamist Parties', Comparative Politics, 35(3); pp.292-312.

Cole, J., \& Cole, S. (2011). 'An Arab Spring for Women', The Nation, 26 April.

Coleman, I. (2012). 'Why the Arab Spring Hasn't Been Better for Women', The Atlantic, 8 March.

Cooke, R. (2008). 'Is this the worst place on earth to be a woman?' The Observer, 11 May.

Crawford, E., Liebling-Kalifani, H., \& Hill, V. (2009). 'Women's Understanding of the Effects of Domestic Abuse: The Impact on Their Identity, Sense of Self and Resilience. A Ground Theory Approach', Journal of International Women's Studies, 11(2); pp. 63-82.

Dabashi, H. (2012). The Arab Spring: The End of Postcolonialism, London: Zed Books.

Dobash, R.E., \& Dobash, R.P. (1998). 'Cross-Border Encounters: Challenges and Opportunities', in R Emerson Dobash and Russell P Dobash, editors, Rethinking Violence Against Women, Thousand Oaks, London and New Delhi: Sage.

Dresch, P. (2000), A History of Modern Yemen, Cambridge: Cambridge University Press.

Erturk, Y., translated from Turkish by Amado, L.Z, \& Geray, I. (2016). Violence without Borders: Paradigm, policy and praxis concerning violence against women, Bethesda MD: Women's Learning Partnership.

Girls Not Brides, Yemen. Rederived from: http://girlsnotbrides.org

Haddad, S. (2012). 'Women's Rights and Revolution in Yemen: A Local Perspective', Muftah, 2 August.

Haj-Yahia, M. M., (2000). 'Wife Abuse and Battering in the Sociocultural Context of Arab Society', Family Process, 39(2); pp.237-255.

Heng, G. (1997). "A Great Way to Fly": Nationalism, the State and the Varieties of Third World Feminism', in Jacqui M Alexander and Chandra Talpade-Mohanty, editors, Feminist Genealogies, Colonial Legacies, Democratic Futures, New York and London: Routledge, 30-45.

Human Rights Watch. (2019), 'Yemen: Events of 2018', https://www.hrw.org/worldreport/2019/country-chapters/yemen

Hutchinson, J., \& Guibernau, M. (2001). Understanding nationalism, Oxford: Polity Press.

International Rescue Committee. (2019). 'Protection, Participation and Potential: Women and Girls in Yemen's War', 25 February.

International Rescue Committee. (2019). ' 4 ways 4 years of war in Yemen has impacted women and girls', 25 March.

IRIN. (2006). 'Yemen: Women call for a 30-percent quota in upcoming elections', UN Office for the Coordination of Humanitarian Affairs, 8 March.

Joseph, S. (1996). 'Patriarchy and development in the Arab world', Gender and Development, 4(2), pp.14-19. 
Kandiyoti, D. (2011). 'Promise and peril: women and the "Arab spring"', Open Democracy, 8 March.

Karman, T. (2018). 'Yemeni Women and Civil Society in Light of Political Transformations and War', Brown Journal of World Affairs, 24(2); pp. 211-223.

Krauss, P. (1987). The Persistence of Patriarchy: Class, Gender and Ideology in Twentieth Century Algeria, New York: Praeger.

Lackner, H. (2017). 'The People's Democratic Republic of Yemen: Unique Socialist Experiment in The Arab World at a Time of World Revolutionary Fervour', International Journal of Postcolonial Studies, 19(5); 677-691.

Lackner, H. (2016). 'The Change Squares of Yemen', in Adam Roberts, Michael J Willis, Rory McCarthy and Timothy Garton Ash, editors, Civil Resistance in the Arab Spring: Triumphs and Disasters, Oxford: Oxford University Press.

Mahmood, S. (2005). 'Feminist Theory, Agency, and the Liberatory Subject', in Fereshteh Nouralie-Simone, editor, On Shifting Ground: Muslim Women in the Global Era, New York: The Feminist Press at the City University of New York.

Maktabi, R. (2010). 'Gender, family law and citizenship in Syria', Citizenship Studies, 14(5); pp. 557-572.

McWilliams, Monica (1998). 'Violence Against Women in Societies Under Stress' in R Emerson Dobash and Russell P Dobash, editors, Rethinking Violence Against Women, Thousand Oaks, London and New Delhi: Sage.

Mir-Hosseini, Z. (2000). Islam and Gender: The Religious Debate in Contemporary Iran, London: I B Tauris.

Oxfam. (2012). 'Yemeni women worse off after uprising', 25 September.

Porter, Joan (2012). 'At USAID-Supported Conference, Yemen's Transitional Prime Minister Endorses Leadership Quota for Women', USAID, 6 April.

Raja, J. A. (2013). 'Yemeni Women in Transition: Challenges and Opportunities', CDDRL Working Papers, Number 10, July. Retrieved from: http://cddrl.stanford.edu.

Sanchez, E., \& Rodriguez, L. (2018). 'These Are the Best and Worst Countries to Be a Woman in 2018', Global Citizen, 18 December.

Shamlan, A. (2012). 'Yemeni women demand more rights', Jerusalem Post, 20 November.

Steans, J. (1998). Gender and International Relations: An Introduction, Cambridge: Polity.

Terry, D.J., Hogg, M.A., \& White, K.M. (2000). 'Attitude-Behavior Relations: Social Identity and Group Membership', in D Terry and M Hogg, editors, Attitude, Behavior and Social Change: The Role of Norms and Group Membership, London: Lawrence Erlbaum, pp.67-94.

Thomson Reuters Foundation. (2019). The world's 10 most dangerous countries for women'. Rederived from: https://poll2018.trust.org

Union Nationale des Femmes de Tunisie. (2002). 'La violence conjugale', in J Vallin and T H Locoh, editors, Population et development en tunisie, Tunis: CERES Editions.

UNFPA. (2016). 'Violence against women escalates under Yemen's brutal conflict', 31 October. 
UNICEF. (2012). Yemen, Retrieved from: https://www.unicef.org/infobycountry/yemen statistics.html

United Nations Foundation. (2017), Yemen: A Brief Background. Retrieved from: https://unfoundation.org/what-we-do/issues/peace-human-rights-and-humanitarianresponse/yemen-a-brief-background/

Yuval-Davis, N. (1997). Gender and Nation, Sage Publications.

Velzeboer, M., \& Novick, J. (2000), 'Violence against women in the Americas: A violation of human rights and an international public health problem', Perspectives in Health, 5(2).

Wagers, S. M. (2015). 'Deconstructing the "Power and Control Motive": Moving Beyond a Unidimensional View of Power in Domestic Violence Theory', Partner Abuse, 6(2); pp .230-242.

Wakekar, N. (2018). "We Are Willing to Die Here": The Fight for Women's Rights in Yemen', New York Times Magazine, 20 November.

Wadekar, N. (2018). 'A man-made war paid for by women and children', Washington Post, 13 December.

Yemen Times. (2010). 'Yemeni 10-year-old raped daily by older husband', 25 February. 